\title{
Quality properties of rice cake containing Artemisia annua L. powder
}

\author{
Eun Woo Moon ${ }^{1}$, Hun Jo Park ${ }^{2}$, Jung Suk Park ${ }^{3}$, Mi Kyung Lee ${ }^{4}$, Hwan Sik Na ${ }^{5 *}$ \\ ${ }^{1}$ Department of Food and Nutrition, Hanyang University, Seoul 04763, Korea \\ ${ }^{2}$ Daesupmalgeun Agricultural Union Corporation, Damyang 57324, Korea \\ ${ }^{3}$ Department of Complementary and Alternative Medicine, Kwangju Womens University, Gwangju 62396, Korea \\ ${ }^{4}$ Department of Food and Nutrition, Gwangju Health University, Gwangju 62287, Korea \\ ${ }^{5}$ Pharmaceutical Chemistry Division, Jeollanamdo Institute of Health and Environment, Muan 58568, Korea
}

\section{개똥쑥 분말을 첨가한 절편의 품질특성}

\author{
문은우 ${ }^{1} \cdot$ 박헌조 $^{2} \cdot$ 박정숙 $^{3} \cdot$ 이미경 ${ }^{4} \cdot$ 나환식 $^{5 *}$ \\ ${ }^{1}$ 한양대학교 식품영양학과, ${ }^{2}$ 대숲맑은영농조합법인, ${ }^{3}$ 광주여자대학교 대체의학과 \\ ${ }^{4}$ 광주보건대학교 식품영양과, ${ }^{5}$ 전라남도보건환경연구원 약품화학과
}

\begin{abstract}
The purpose of this study was to determine the optimum amount of Artemisia annua $\mathrm{L}$. powder for adding rice flour. The $A$. annua powder was added to the rice flour at ratios of $1 \%(30 \mathrm{~g} / 3 \mathrm{~kg}), 2 \%(60 \mathrm{~g} / 3 \mathrm{~kg}), 3 \%(90$ $\mathrm{g} / 3 \mathrm{~kg}, \mathrm{w} / \mathrm{w})$. As the amount of $A$. annua powder in rice cake dough increased, carbohydrate, ash content, total amino acid, and dietary fiber contents increased whereas the moisture content decreased. Hunter's $L$ value decreased as $A$. annua powder content increased. On the contrary, the a- and $b$ values increased. The sensory score of the rice cakes containing $30 \mathrm{~g}$ of $A$. annua powder was the highest of all the rice cakes tested. Based on these results, adding $A$. annua powder could improve the quality and sensory characteristics of rice cake.
\end{abstract}

Key words: Artemisia annua L., rice cake, quality properties, sensory characteristics

\section{서 론}

한국의 전통음식인 절편은 멥쌀을 가루로 빻아 물과 반 죽하여 충분히 증숙한 다음 떡메로 쳐서 매끄럽고 촉촉하고 쫄깃한 질감을 갖는 떡류에 속한다(1). 이러한 절편은 대표 적인 쌀 가공식품이라는 긍정적 이미지와 함께 알레르기를 유발하지 않는 안전하고 건강식품으로 재평가 받고 있다 (2).

지금까지 절편에 관한 연구는 많이 이루어져 왔으며, 최 근 건강에 대한 관심이 증가하면서, 유자 잎을 첨가한 절편 (3), 댓잎 분말을 첨가한 절편(4), 연잎 첨가 절편(5) 등 여러

*Corresponding author. E-mail : hsna0103@korea.kr Phone : 82-61-240-5283, Fax : 82-61-240-5285

Received 13 March 2015; Revised 5 August 2015; Accepted 16 October 2015.

Copyright (c) The Korean Society of Food Preservation. All rights reserved.
가지 천연 재료를 이용한 연구가 많이 진행되고 있다. 한국 의 전통식품인 절편의 표준화 및 지속적인 품질 유지를 위해서는 표준화된 절편의 제조공정도 중요하지만 각 재료 의 특성에 따른 배합비율이 매우 중요하다고 볼 수 있다.

쑥은 국화과(Compositae), 쑥속(Artemisia)에 속하는 생 명력과 번식력이 강한 다년생 초본으로 한국의 산야에 널리 자생하고 있으며, 영양학적으로 우수한 식품으로 알려져 있다(6). 최근 쑥은 항암, 항산화, 항균 및 가축의 사료로 이용가능성 등의 기능성에 관한 연구가 수행되어 왔으며, 여러 가지 식품에 응용하고자 하는 시도가 활발하게 이루어 지고 있다(7-10).

그 중 개똥쑥(Artemisia annua L.)은 국화과에 속하는 일 년생 초본으로 세계적으로 널리 분포되어 있으며, 한국에 서는 전국 각지의 길가나 들판에 무리지어 야생하고 있다 (11).

중국에서는 예로부터 말라리아 치료를 위한 약초로 사용 되어 왔는데, 최근 chlorogenic acid, salicylic acid 등의 
phenolic acid와 epicatechin 등의 catechin 류와 같은 성분들 의 높은 항산화 및 항암활성이 입증됨으로서 세계적으로 주목받고 있는 생약제로 평가되고 있다(12).

한국에서는 개똥쑥에 관한 연구로는 개똥쑥의 영양학적 특성 및 생리활성(11), 항암활성(12), 전초의 총 페놀 화합물 함량에 기인한 항산화 활성(13), 수용성 추출물에 대한 항곰 팡이 활성(14) 등이 있다. 이처럼 개똥쑥에 관한 연구는 천연물학, 약학 등의 관점에서 주로 이루어져 왔으며, 개똥 쑥을 이용한 가공제품에 관한 연구는 거의 없는 실정이다. 따라서 본 연구에서는 개똥쑥을 이용한 가공식품을 개발 하고자 생리적 기능이 우수한 개똥쑥 분말을 부원료로 첨가 한 절편을 제조하여 영양성분, 물성 특성 및 관능특성을 비교하여 멥쌀가루에 대한 개똥쑥 분말의 최적 배합비를 제시하고자 하였다.

\section{재료 및 방법}

\section{실험재료}

실험에 사용된 개똥쑥 $(A$ annua $\mathrm{L}$.)은 담양군(2013년)에 서 채취하여 잘 씻은 다음 세절하여 $80^{\circ} \mathrm{C}$ 에서 2 일간 열풍건 조(WOF-W155, Daihan Scientific, Wonju, Korea)한 후 마쇄 하여 $100 \mathrm{mesh}$ 이하의 분말로 제조하여 첨가시료로 사용하 였다. 멥쌀(Naju, Korea), 천일염(Docho Nonghyup, Shinan, Korea), 정제염(Hanju Co., Ltd., Ulsan, Korea), 설탕 등은 시중 농협에서 구입하여 사용하였다.

\section{절편의 제조}

절편은 개똥쑥 $(A$ annua $\mathrm{L}$.$) 분말의 첨가 비율을 달리하$ 여 아래와 같은 재료 배합비로 제조하였다. 즉, 멥쌀 $3 \mathrm{~kg}$ 을 기준으로 개똥쑥 분말을 각각 $0 \mathrm{~g}, 30 \mathrm{~g}, 60 \mathrm{~g}, 90 \mathrm{~g}$ 을 첨가하 였으며, 소금 $(40 \mathrm{~g})$, 물 $(1,000 \mathrm{~mL})$, 설탕 $(150 \mathrm{~g})$ 은 전 시료군 에 일정하게 첨가하여 절편을 제조하였다. 먼저 멥쌀 $3 \mathrm{~kg}$ 을 물에 12 시간 정도 불린 다음 소금 $40 \mathrm{~g}$ 을 넣고 가루로 분쇄 한 후, 물 $500 \mathrm{~mL}$ 와 개똥쑥 분말 $30 \mathrm{~g}, 60 \mathrm{~g}, 90 \mathrm{~g}$ 을 각각 넣고 고루 섞어주었다. 분쇄한 쌀가루는 한번 더 곱게 분쇄 한 후 쌀가루에 물 $500 \mathrm{~mL}$ 와 설탕 $150 \mathrm{~g}$ 을 넣고 반죽한 후, 성형하였다. 성형한 반죽을 $-40^{\circ} \mathrm{C}$ 에서 6 시간 정도 급냉 한 다음, $100^{\circ} \mathrm{C}$ 에서 20 분간 쪄서 절편을 제조하고 상온으로 식힌 후 서로 겹치지 않게 Ziploc $(45 \times 30 \mathrm{~cm}$, Johnson, Seoul, $\mathrm{Korea)}$ 으로 포장하여 $-20^{\circ} \mathrm{C}$ 냉동고에 보관하면서 시료로 사용하였으며, 대조구로서 개똥쑥을 넣지 않은 절편을 제 조하여 사용하였다.

\section{일반성분}

개똥쑥 분말을 첨가한 절편의 일반성분은 $\mathrm{AOAC}$ 방법
(15)과 식품공전(16)에 따라 분석하였다. 즉, 수분은 상압가 열건조법, 조회분은 건식회화법, 조지방은 Soxhlet 추출법, 조단백질은 자동질소증류장치를 이용한 micro Kjeldahl 법 으로 각각 분석하였으며, 탄수화물은 전체 $100 \%$ 에서 수분, 조단백질, 조지방과 회분의 \%함량을 제외한 값으로 하였 다.

\section{유리아미노산}

시료(절편)에 $75 \%$ ethanol을 가하여 수옥상에서 30 분간 추출한 후 여과하여 sodium citrate buffer(pH 2.2)에 용해한 다음 Sep-pak $\mathrm{C}_{18}$ cartridge(Vac $6 \mathrm{CC}$, Waters, Ireland, USA) 를 통과시키고 $0.45 \mu \mathrm{m}$ membrane filter(Millipore Co., USA) 로 여과한 후 아미노산 전용분석기(10 Avp series, Shimadzu, Kyoto, Japan)로 분석하였다(17).

\section{색 도}

절편의 색도는 색차계(TC-3600, Tokyo Denshoku Co., Ltd., Tokyo, Japan)를 사용하여 Hunter 색차계인 lightness를 나타내는 L값, greenness를 나타내는 -a값, yellowness를 나 타내는 $\mathrm{b}$ 값 및 색차 $(\mathrm{EE}$, color difference)값으로 나타내었다 (18). 측정은 10 회 이상 반복 측정한 후 평균값으로 나타내 었으며, $\Delta \mathrm{E}$ 는 대조구 즉, 개똥쑥 분말을 첨가하지 않은 절편 과 개똥쑥 분말을 일정량 첨가한 절편을 비교한 색차값의 차이를 의미한다. 이때 사용한 표준백판은 $\mathrm{L}=90.5, \mathrm{a}=0.4$, $\mathrm{b}=3.5$ 였다.

\section{유리당}

유리당은 Gancedo 등의 방법(19)에 따라 시료에 증류수 를 가하여 실온에서 4 시간 추출한 다음 추출물을 Sep-pak $\mathrm{C}_{18}$ cartridge로 정제한 후 $0.45 \mu \mathrm{m}$ membrane filter로 여과한 후 high performance liquid chromatography(HPLC-RID, Shiseido nanospace SI-2, Tokyo, Japan)를 이용하여 분석하 였다.

\section{식이섬유}

절편의 식이섬유는 식품공전 방법(16)에 따라 열풍건조 기(WOF-W155, Daihan Scientific, Seoul, Korea)를 이용하 여 건조된 시료에 a-amylase, protease, amylo-glucosidase 효소로 연속적으로 분해하여 단백질을 제거한 후 ethanol로 처리하여 침전시켜 여과하고 ethanol과 acetone으로 세척한 후 열풍건조하여 무게를 확인하여 측정하였다.

\section{관능검사}

관능검사는 대학교 학생 중 선별하여 실험목적을 설명하 고 각 특성치에 대하여 반복하여 훈련시킨 후 색(color), 향(flavor), 맛(taste), 조직감(texture), 전반적인 기호도 (overall acceptability)를 7점 채점법으로 평가하였다. 시료 
는 관능검사 시작 10 분 전에 관능검사용 그릇에 담아 관능 검사원에게 평가하도록 제시하였고, 3회 반복 실시하였다.

\section{통계처리}

각 실험은 3 회 반복하여 얻은 결과를 평균과 표준편차로 나타내었으며, 그 결과는 SAS package(8.2, SAS Institute Inc., Cary, NC, USA)로 통계처리 하였으며, 시료간의 항목 별 유의성 검증 $(\mathrm{p}<0.05)$ 은 Duncan's multiple range test로 검증하였다.

\section{결과 및 고찰}

\section{절편의 일반성분}

개똥쑥 분말을 일정 비율로 첨가하여 제조한 절편의 일 반성분을 분석한 결과는 Table 1과 같다. 수분(48.9 53.2\%) 과 탄수화물(42.5 46.6\%)이 가장 많은 비중을 차지하였고, 조단백질(2.7 2.9\%), 조지방(0.5 1.1\%), 회분(0.6 0.7\%) 순 으로 나타났다. 성분별 분석에서 개똥쑥 분말 첨가 농도가 높아질수록 수분 함량은 $53.2 \%$ 에서 $49.8 \%$ 로 낮아졌으며, 탄수화물과 회분 함량은 다소 증가하는 경향을 보였다.

농촌진흥청에서 제공하는 식품성분표(20) 중 쑥은 수분 을 제외하면 탄수화물 $20.0 \%$, 섬유소가 $4.7 \%$ 로 상대적으로 함량이 높아 이를 첨가한 절편의 탄수화물 함량이 증가하는 것으로 사료된다. 또한 Ryu 등(21)은 자연건조한 개똥쑥의 일반성분을 분석한 결과 수분함량이 $12.5 \%$, 조단백질 $9.4 \%$, 조지방 $11.2 \%$ 와 회분 함량이 $11.2 \%$ 라고 보고하여 수분함량에 따라 영양성분이 다른 결과를 보였으며 상대적 으로 조섬유 등 탄수화물 함량이 높은 비율을 차지하였다.

$\mathrm{Kim}$ 등(22)은 천년초 분말을 첨가한 절편의 일반성분을 분석한 결과 첨가량에 따라 수분함량과 조단백질 함량은 감소하였으나 조회분과 조지방 함량은 증가하는 경향을 보였다. 따라서 첨가하는 재료에 따라 절편의 일반성분 함 량이 상대적으로 변하는 것을 알 수 있었다.

Table 1. Proximate compositions of rice cake containing different amounts of $A$ annua $\mathrm{L}$. powder

\begin{tabular}{ccccc}
\hline & \multicolumn{3}{c}{ Substitution level of $A$} & annua $\mathrm{L}$. powder $(\mathrm{g})$ \\
\cline { 2 - 5 } & Control & 30 & 60 & 90 \\
\hline Moisture & $53.2 \pm 0.5^{\mathrm{a} 1)}$ & $52.0 \pm 0.2^{\mathrm{b}}$ & $50.3 \pm 0.9^{\mathrm{c}}$ & $48.9 \pm 0.3^{\mathrm{d}}$ \\
Crude protein & $2.7 \pm 0.1^{\mathrm{a}}$ & $2.9 \pm 0.1^{\mathrm{a}}$ & $2.9 \pm 0.1^{\mathrm{a}}$ & $2.9 \pm 0.1^{\mathrm{a}}$ \\
Crude fat & $1.1 \pm 0.1^{\mathrm{a}}$ & $0.6 \pm 0.1^{\mathrm{c}}$ & $0.5 \pm 0.1^{\mathrm{c}}$ & $0.8 \pm 0.1^{\mathrm{b}}$ \\
Ash & $0.6 \pm 0.1^{\mathrm{a}}$ & $0.6 \pm 0.1^{\mathrm{a}}$ & $0.7 \pm 0.1^{\mathrm{a}}$ & $0.7 \pm 0.1^{\mathrm{a}}$ \\
Carbohydrate $^{2)}$ & $42.5 \pm 0.6^{\mathrm{d}}$ & $43.8 \pm 0.4^{\mathrm{c}}$ & $45.5 \pm 0.6^{\mathrm{b}}$ & $46.6 \pm 0.4^{\mathrm{a}}$ \\
\hline
\end{tabular}

${ }^{11}$ Mean \pm standard deviation $(\mathrm{n}=3)$. Means with same letter in a row are not significantly different at $p<0.05$ level.

${ }^{2)} 100$-(sum of moisture, crude fat, crude lipid and ash).
유리아미노산

개똥쑥 함량을 달리하여 제조한 절편의 유리아미노산 분석 결과는 Table 2 와 같다. 총 유리아미노산 함량의 경우 개똥쑥 분말을 첨가하지 않은 무첨가구의 경우 $1.0 \mathrm{mg} / \mathrm{kg}$ 으 로 나타났으며 개똥쑥 분말을 첨가할수록 총 유리아미노산 함량은 증가하는 경향을 보여 개똥쑥 분말 첨가가 절편의 유리아미노산 함량에 영향을 주는 것으로 사료된다.

주요 유리아미노산은 allo-hydroxylysine, serine, aspartic acid 및 isoleucine이 대부분을 차지하고 있었으며 나머지 성분은 미량 검출되었다. 특히 allo-hydroxylysine과 isoleucine 의 경우 개똥쑥 분말을 첨가한 절편에서 함량이 증가하여 전체 유리아미노산 함량 증가에 영향을 주는 성분으로 나타 났다.

Table 2. Total free amino acid compositions of rice cake containing different amounts of $A$ annua $\mathrm{L}$. powder

$(\mathrm{mg} / \mathrm{kg})$

\begin{tabular}{lcccc}
\hline & \multicolumn{3}{l}{ Substitution level of $A$} & annua $\mathrm{L} \cdot$ powder $(\mathrm{g})$ \\
\cline { 2 - 5 } & Control & 30 & 60 & 90 \\
\hline Taurine & 0.01 & 0.01 & 0.01 & 0.02 \\
Aspartic acid & 0.06 & 0.05 & 0.07 & 0.13 \\
Threonine & $\mathrm{ND}^{1)}$ & $\mathrm{ND}$ & $\mathrm{ND}$ & $\mathrm{ND}$ \\
Serine & 0.11 & 0.12 & 0.09 & 0.14 \\
Glutamic acid & 0.02 & 0.02 & 0.02 & 0.02 \\
Sarcosine & 0.05 & 0.06 & 0.08 & 0.12 \\
Proline & $\mathrm{ND}$ & $\mathrm{ND}$ & $\mathrm{ND}$ & $\mathrm{ND}$ \\
Glycine & $\mathrm{ND}$ & $\mathrm{ND}$ & $\mathrm{ND}$ & $\mathrm{ND}$ \\
Alanine & 0.01 & 0.02 & 0.03 & 0.05 \\
Citrulline & 0.05 & 0.05 & 0.06 & 0.07 \\
a-aminobutyric acid & $\mathrm{ND}$ & $\mathrm{ND}$ & $\mathrm{ND}$ & $\mathrm{ND}$ \\
Valine & 0.01 & 0.01 & 0.01 & 0.02 \\
Methionine & 0.01 & 0.01 & 0.03 & 0.05 \\
Isoleucine & 0.02 & 0.09 & 0.13 & 0.16 \\
Leucine & $\mathrm{ND}$ & $\mathrm{ND}$ & 0.01 & 0.01 \\
Tyrosine & $\mathrm{ND}$ & 0.01 & 0.01 & 0.01 \\
Phenylalanine & 0.02 & 0.04 & 0.04 & 0.07 \\
B-alanine & 0.01 & 0.01 & 0.01 & 0.02 \\
Histidine & $\mathrm{ND}$ & $\mathrm{ND}$ & $\mathrm{ND}$ & $\mathrm{ND}$ \\
allo-Hydroxylysine & 0.58 & 0.62 & 0.66 & 0.71 \\
Ornithine & 0.04 & 0.04 & 0.04 & 0.07 \\
Lysine & $\mathrm{ND}$ & $\mathrm{ND}$ & $\mathrm{ND}$ & $\mathrm{ND}$ \\
Arginine & $\mathrm{ND}$ & $\mathrm{ND}$ & $\mathrm{ND}$ & $\mathrm{ND}$ \\
\hline \multicolumn{1}{c}{ Total } & 2.00 & 31.16 & 61.30 & 91.67 \\
\hline
\end{tabular}

${ }^{1)} \mathrm{ND}$, not detected. 
$\operatorname{Ryu}(23)$ 는 개똥쑥 잎과 줄기의 유리아미노산 조성을 비 교한 결과 잎에서 약 2 배 이상 높게 정량되었으며, proline 함량이 가장 높다고 보고하였으며, 이러한 차이에 의해 쑥 의 잎과 줄기의 맛이 다소 상이하게 나타나는 중요한 인자 중의 하나라고 보고하였다.

\section{절편의 색도}

개똥쑥 분말을 첨가하여 제조한 절편의 색도를 측정한 결과는 Table 3 과 같다. L값의 경우 개똥쑥을 첨가하지 않은 무첨가구의 경우 $77.75 \pm 1.09$ 이었으며, 개똥쑥 분말 $30 \mathrm{~g}$ 첨가 절편이 $59.25 \pm 0.36,60 \mathrm{~g}$ 첨가 제품이 $52.10 \pm 0.54,90$ $\mathrm{g}$ 첨가구가 $46.68 \pm 0.66$ 으로 개똥쑥 분말 첨가량이 증가하 면서 $\mathrm{L}$ 값이 감소하여 색이 어두어지는 경향을 보였다. $\mathrm{a}$ 값 의 경우 무첨가구가 $-2.34 \pm 0.13$ 에서 $90 \mathrm{~g}$ 첨가구가 $-0.47 \pm 0.05$ 로 증가하는 결과를 보였으며, $\mathrm{b}$ 값도 $\mathrm{a}$ 값과 같은 경향을 보여 개똥쑥 분말 첨가량과 정의 상관관계를 보였다.

Lee 등(24)은 대잎 분말을 절편에 첨가하여 색도를 측정 한 결과 대잎 분말 첨가량이 증가할수록 $\mathrm{L}$ 값은 낮아져 어두 운 색을 나타냈으며, $\mathrm{a}$ 값은 모두 -값을 보였으며, 첨가량에 따라 값이 증가하였다고 보고하였는데, 본 실험 결과와 비 슷한 경향을 보였다.

색도의 변화정도를 나타내는 $\Delta \mathrm{E}$ 값은 개똥쑥 분말 30 $\mathrm{g}$ 첨가 절편이 20.51로 나타났으며, 첨가 정도에 따라 증가 하는 결과를 보였다. 이러한 결과는 NBS(Natural Bureau of Standard의 기준(25)에 따라 상당한 변화가 있는 것으로 간주되는 3.0 이상의 값을 보여 개똥쑥 분말 첨가가 절편 고유의 색에 영향을 주는 것으로 나타났다. NBS 기준에서 나타내는 색차값의 범위는 0 0.5, 0.5 1.5, 1.5 3.0이면 각각 trace, slight, noticeable한 정도의 육안적인 차이에 해당한 다. NBS 기준은 감각적인 색의 차이와 잘 대응하므로 널리 이용되고 있다. 일반적인 사람이 떨어져 있는 2 색 간의 차이 가 없다고 인정하는 색의 허용 차이는 $\Delta \mathrm{E} \leqq 3$ 이라고 한다 (24).

Table 3. Hunter's color value of rice cake containing different amounts of $A$ annua L. powder

\begin{tabular}{ccccc}
\hline & \multicolumn{4}{c}{ Substitution level of $A$ annua L. powder $(\mathrm{g})$} \\
\cline { 2 - 5 } & Control & 30 & 60 & 90 \\
\hline L (lightness) & $77.75 \pm 1.09^{\mathrm{a} 1)}$ & $59.25 \pm 0.36^{\mathrm{b}}$ & $52.10 \pm 0.54^{\mathrm{c}}$ & $46.68 \pm 0.66^{\mathrm{d}}$ \\
$-\mathrm{a}$ (greenness) & $-2.34 \pm 0.13^{\mathrm{a}}$ & $-1.03 \pm 0.11^{\mathrm{b}}$ & $-0.79 \pm 0.06^{\mathrm{c}}$ & $-0.47 \pm 0.05^{\mathrm{d}}$ \\
$\mathrm{b}$ (yellowness) & $8.23 \pm 0.35^{\mathrm{d}}$ & $17.00 \pm 0.13^{\mathrm{c}}$ & $19.43 \pm 0.59^{\mathrm{b}}$ & $20.18 \pm 0.32^{\mathrm{a}}$ \\
$\Delta \mathrm{E}$ & 0 & 20.51 & 28.03 & 33.34 \\
\hline${ }^{1}$ Mean $\mathrm{M}$ standard deviation $(\mathrm{n}=10)$. Means with same letter in a row are not significantly \\
different at $\mathrm{p}<0.05$ level.
\end{tabular}

\section{유리당 및 식이섬유 함량}

절편의 유리당 함량을 분석한 결과(Table 4), 모든 시료에
서 glucose와 fructose는 검출되지 않았으며 sucrose만 검출 되었다. Sucrose의 경우 개똥쑥 분말을 첨가하지 않은 무첨 가구가 $2.50 \pm 0.04 \%$ 로 나타났으며, $90 \mathrm{~g}$ 첨가구가 $3.04 \pm$ $0.03 \%$ 로 개똥쑥 분말 첨가량이 많아지면서 sucrose 함량이 증가하는 결과를 보였다.

식이섬유를 분석한 결과 무첨가구가 $0.15 \pm 0.01 \%$ 로 나타 나 시료 중 가장 낮은 결과를 보였으며, $30 \mathrm{~g}$ 첨가구가 $2.64 \pm 0.02 \%, 60 \mathrm{~g}$ 첨가구가 $2.96 \pm 0.02 \%, 90 \mathrm{~g}$ 첨가구가 $3.04 \pm 0.03 \%$ 로 나타나 개똥쑥 분말 첨가량이 증가할수록 절편에 함유된 식이섬유 함량이 증가하는 것으로 나타났다.

Brisibe 등(27)은 개똥쑥의 부위별 섬유소 함량을 분석한 결과, 섬유소 함량이 높았으며, 특히 소화성 섬유소의 비율 이 높아 가축의 사료 등에 이용가치가 높은 것으로 보고하 여 개똥쑥 분말의 식이섬유가 절편의 식이섬유 함량에 영향 을 준 것으로 사료된다.

Table 4. Total free sugar and dietary fiber contents of rice cake containing different amounts of $A$ annua $\mathrm{L}$. powder

\begin{tabular}{ccccc}
\hline & & & & (unit : \%) \\
\cline { 2 - 5 } & \multicolumn{3}{c}{ Substitution level of $A$} & annua L. powder $(\mathrm{g})$ \\
\hline Control & 30 & 60 & 90 \\
\hline Dietary fiber & $2.50 \pm 0.04^{\mathrm{d} 1)}$ & $2.64 \pm 0.02^{\mathrm{c}}$ & $2.96 \pm 0.02^{\mathrm{b}}$ & $3.04 \pm 0.03^{\mathrm{a}}$ \\
\hline
\end{tabular}

${ }^{1)}$ Mean \pm standard deviation $(n=3)$. Means with same letter in a row are not significantly different at $\mathrm{p}<0.05$ level.

관능검사

개똥쑥 분말을 첨가하여 제조한 절편의 관능검사 결과는 Table 5와 같다. 관능에 따른 시료별 선호도 결과 색(color) 은 $90 \mathrm{~g}$ 첨가 시료가 가장 높은 점수를 받았으며, 향미 (flavor), 맛(taste), 식감(chewiness)은 $30 \mathrm{~g}$ 첨가 시료가 가장 높은 값을 나타냈다. 특히 향미와 맛은 개똥쑥 함유량에 따라 유의한 차이를 보였으나, 색과 식감은 유의적인 차이 를 보이지 않는 것으로 나타났다.

색의 경우 개똥쑥 $90 \mathrm{~g}$ 첨가 시료가 $5.90 \pm 1.74$ 로 가장 높은 점수를 얻었으며, $60 \mathrm{~g}$ 첨가 시료 $(5.80 \pm 1.47), 30 \mathrm{~g}$

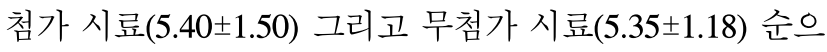
로 나타났다. 그러나 시료 간에는 통계적으로 유의한 선호 도 차이는 없었다. 향미의 경우 개똥쑥 $30 \mathrm{~g}$ 첨가 시료가 $5.90 \pm 1.33$ 으로 가장 높게 나타났으며, $60 \mathrm{~g}$ 첨가 시료

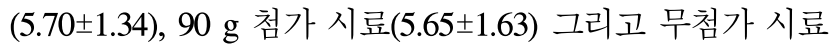
(4.35 \pm 1.31$)$ 순으로 나타났으며, 무첨가 시료보다 통계적으 로 유의하게 선호도가 높았다 $(\mathrm{p}<0.05)$.

맛은 개똥쑥 $30 \mathrm{~g}$ 첨가 시료가 $5.95 \pm 1.28$ 으로 가장 높은 점수를 얻었으며, 무첨가 시료(4.75 \pm 1.41$), 60 \mathrm{~g}$ 첨가 시료

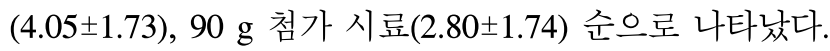
개똥쑥 $30 \mathrm{~g}$ 첨가 시료가 타 시료보다 통계적으로도 유의하 
게 선호도가 높은 결과를 보였다( $\mathrm{p}<0.05)$. 식감의 경우 개똥 쑥 $30 \mathrm{~g}$ 첨가 시료가 $5.45 \pm 1.23$ 으로 가장 높은 점수를 얻었

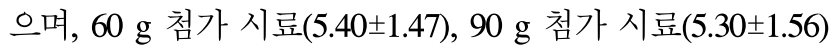

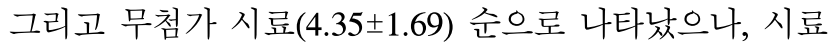
간에는 유의한 선호도 차이를 보이지 않았다.

전반적 기호도는 개똥쑥 $30 \mathrm{~g}$ 첨가된 시료가 $5.75 \pm 1.33$ 으

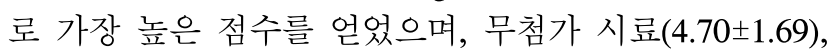

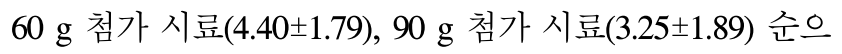
로 나타났다. 전반적 기호도와 다양한 관능검사결과를 종 합하여 볼 때 개똥쑥 $30 \mathrm{~g}$ 을 첨가하여 제조한 개똥쑥 절편의 소비자 선호도가 가장 높다는 것을 알 수 있었다.

Table 5. Sensory characteristics of rice cake containing different amounts of $A$ annua $\mathrm{L}$. powder

\begin{tabular}{ccccc}
\hline & \multicolumn{4}{c}{ Substitution level of $A$ annua L. powder $(\mathrm{g})$} \\
\cline { 2 - 5 } & Control & 30 & 60 & 90 \\
\hline Color & $5.35 \pm 1.18^{\mathrm{al})}$ & $5.40 \pm 1.50^{\mathrm{a}}$ & $5.80 \pm 1.47^{\mathrm{a}}$ & $5.90 \pm 1.74^{\mathrm{a}}$ \\
Flavor & $4.35 \pm 1.31^{\mathrm{a}}$ & $5.90 \pm 1.33^{\mathrm{b}}$ & $5.70 \pm 1.34^{\mathrm{b}}$ & $5.65 \pm 1.63^{\mathrm{b}}$ \\
Taste & $4.75 \pm 1.41^{\mathrm{b}}$ & $5.95 \pm 1.28^{\mathrm{c}}$ & $4.05 \pm 1.73^{\mathrm{b}}$ & $2.80 \pm 1.74^{\mathrm{a}}$ \\
Chewiness & $4.35 \pm 1.69^{\mathrm{a}}$ & $5.45 \pm 1.23^{\mathrm{a}}$ & $5.40 \pm 1.47^{\mathrm{a}}$ & $5.30 \pm 1.56^{\mathrm{a}}$ \\
Overall & $4.70 \pm 1.69^{\mathrm{bc}}$ & $5.75 \pm 1.33^{\mathrm{c}}$ & $4.40 \pm 1.79^{\mathrm{b}}$ & $3.25 \pm 1.89^{\mathrm{a}}$ \\
acceptability & & & & \\
\hline
\end{tabular}

${ }^{1)}$ Mean \pm standard deviation $(\mathrm{n}=3)$. Means with same letter in a row are not significantly different at $\mathrm{p}<0.05$ level.

\section{요 약}

본 연구는 개똥쑥 분말 $(0 \mathrm{~g}, 30 \mathrm{~g}, 60 \mathrm{~g}, 90 \mathrm{~g})$ 을 반죽에 첨가하여 절편을 제조하고 절편의 영양성분, 색도, 아미노 산 및 관능검사를 실시하여 개똥쑥 절편의 적합한 첨가비율 과 최적 조건을 제시하고자 실시하였다. 일반성분의 경우 개똥쑥 분말 첨가 농도가 높아질수록 수분 함량은 낮아졌으 며 탄수화물과 회분 함량은 다소 증가하는 경향을 보였다. 총 유리아미노산 함량은 개똥쑥 분말을 첨가할수록 유의적 으로 증가하는 경향을 보여 개똥쑥 분말 첨가가 절편의 유리아미노산 함량에 영향을 주는 것으로 판단된다. 색도 를 분석한 결과 명도를 나타내는 $\mathrm{L}$ 값의 경우 개똥쑥 분말 첨가량이 증가하면서 감소하는 경향을 보였고, 녹색도를 나타내는 $-\mathrm{a}$ 값, 황색도를 나타내는 $\mathrm{b}$ 값은 개똥쑥 분말 첨가 량이 증가할수록 증가하는 경향을 보였다. 유리당을 분석 한 결과 sucrose만 검출되었으며 개똥쑥 분말 첨가량이 많 아지면서 sucrose 함량이 증가하는 결과를 보였으며, 식이 섬유 함량도 첨가량에 따라 증가하는 것으로 나타났다. 관 능에 따른 시료별 선호도 결과 색(color)은 $90 \mathrm{~g}$ 첨가 시료가 향미(flavor), 맛(taste), 식감(chewiness)은 $30 \mathrm{~g}$ 첨가 시료가 가장 높은 값을 나타냈다. 전반적 기호도와 다양한 관능검
사결과를 종합하여 볼 때 개똥쑥 분말 $30 \mathrm{~g}$ 을 첨가하여 제조한 개똥쑥 떡의 선호도가 가장 높다는 것을 알 수 있다.

\section{감사의 글}

본 연구는 중소기업청에서 시행한 중소기업 기술개발사 업의 지원에 의해 수행된 기술개발결과의 일부이며 그 지원 에 감사드립니다.

\section{References}

1. Chae KY, Hong JS (2007) The quality characteristics of jeolpyon with different amounts of job's tears flour. Korean J Food Cookery Sci, 23, 770-776

2. Choi HJ, Lee HW, Yoon S (2013) Fermentation of rice flour with Weissella koreensis $\mathrm{HO} 20$ and Weissella kimchii $\mathrm{HO} 22$ isolated from kimchi and its use in the making of jeolpyeon. Korean J Food Cookery Sci, 29, 267-274

3. Joo HS, Park JE, Jang MS (2010) Preference and quality characteristics of jeolpyoun containing citron leaf powder. Korean J Food Cookery Sci, 26, 110-120

4. Lee GH, Kim MK (2010) A study on the quality characteristics of jeolpyun with bamboo leaf powder. Korean J Food Culture, 25, 770-778

5. Han KY, Yoo SJ (2007) Quality characteristics of lotus leaf jeolpyun during storage. J Korean Soc Food Sci Nutr, 36, 1604-1611

6. Haw IW, Lee SD, Hwang WI (1985) A study on the nutritional effects in rats by feeding basal diet supplemented with mugwort powder. J Korean Soc Food Nutr, 14, 123-130

7. Lee SD, Park HH, Kim DW, Bang BH (2000) Bioactive constituents and utilities of Artemisia sp. as medical herb and foodstuff. Korean J Food Nutr, 13, 490-505

8. Lee GD, Kim JS, Bae JO, Yoon HS (1992) Antioxidative effectiveness of water extract and ether extract in worm wood. Korean Soc Food Nutr, 21, 17-22

9. Hong JH, Jeon JL, Lee JH, Lee IS (2007) Antioxidative properties of Artemisia princeps Pamp. J Korean Soc Food Sci Nutr, 36, 657-662

10. Jung MJ, Yin Y, Heo SI, Wang MH (2008) Antioxidative and anticancer activities of extract from Artemsia capollaries. Korean J Pharmacogn, 39, 194-198

11. Ryu JH, Kim RJ, Lee SJ, Kim IS, Lee HJ, Sung NJ 
(2011) Nutritional properties and biological activities of Artemisia annua L.. J Korean Soc Food Sci Nutr, 40, 163-170

12. Ryu JH, Lee SJ, Kim MJ, Shin JH, Kang SK, Cho KM, Sung NJ (2011) Antioxidant and anticancer activities of Artemisia annua L. and determination of functional compounds. J Korean Soc Food Sci Nutr, 40, 509-516

13. Kim KB, Yoo KH, Park HY, Jeong JM (2006) Anti-oxidatives activities of commercial edible plant extracts distributed in Korea. J Korean Soc Appl Biol Chem, 49, 328-333

14. Kim HC, Kil BS, Lee YH (2001) The antifungal activity of chemical substances from Artemisia annua. Korean J Ecol, 24, 137-140

15. AOAC (1990) Official Methods of Analysis. 15th ed, Association Official Analytical Chemists, Washington DC, USA

16. KFDA (2005) Food Code. A separate volume, Munyoungsa, Seoul, Korea, p 3-29

17. Waters Associates (1990) Analysis of amino acid by PICO.TAG System. Young-in scientific Co., Ltd., Seoul, Korea, p 41-46

18. Choi HC, OH SK (1996) Diversity and function of pigments in colored rice. Korean J Crop Sci, 41, 1-9

19. Gancedo M, Luh BS (1986) HPLC analysis of organic acids and sugars in tomato juice. J Food Sci, 51, 571-573

20. RDA (2006) Food Composition Table. National Rural
Resources Development Institute, 7th ed, Suwon, Korea, p 150-151

21. Ryu JH, Kim RJ, Lee SJ, Kim IS, Lee HJ, Sung NJ (2011) Nutritional properties and biological activities of Artemisia annua L. J Korean Soc Food Sci Nutr, 40, 163-170

22. Kim MH, Hong GJ (2009) Quality properties of jeolpyun supplemented with cheonnyuncho. Korean J Food Cookery Sci, 25, 415-420

23. Ryu JH (2011) Determination of biological activities and functional compounds from gaeddongssuk (Artemisia annua L.). $\mathrm{Ph} \mathrm{D}$ Thesis. Gyeongsang National University, Korea, p 33

24. Lee GH, Kim MK (2010) A study on the quality characteristics of jeolpyun with bamboo leaf powder. Korean J Food Culture, 25, 770-778

25. Kang KH, No BS, Seo JH, Hu WD (1997) Food Analysis, Sungkyunkwan University Acedemic Press, Seoul, p 387-394

26. Judd DG, Wyszecki G (1964) Applied colorific science for industry and business. Diamond Co., Japan, p 333-334

27. Brisibe EA, Umoren UE, Brisibe F, Magalhaes PM, Ferreira JFS, Luthria D, Wux Prior RL (2009) Nutritional characterization and antioxidant capacity of different tissues of Artemisia annua L.. Food Chem, 115, 1240-1246 